\title{
ANALYSIS OF GROWTH INTENSITY AND CARCASS CHARACTERISTICS OF WAGYU-ABERDEEN ANGUS CROSSBRED STEERS
}

\author{
Renáta Toušovái, Jaromír Ducháček ${ }^{1}$ Matúš Gašparík¹, \\ Martin Ptáček ${ }^{1}$, Lubor Kitzler ${ }^{1}$ \\ ${ }^{1}$ Department of Animal Husbandry, Faculty of Agrobiology, Food and Natural Resources, Czech University of Life \\ Sciences, Kamýcká 129, 165 00, Prague 6 - Suchdol, Czech Republic
}

\begin{abstract}
TOUŠOVÁ RENÁTA, DUCHÁČEK JAROMÍR, GAŠPARÍK MATÚŠ, PTÁČEK MARTIN, KITZLER LUBOR. 2018. Analysis of Growth Intensity and Carcass Characteristics of Wagyu-Aberdeen Angus Crossbred Steers. Acta Universitatis Agriculturae et Silviculturae Mendelianae Brunensis, 66(4): 897-903.

The aim of this study was to evaluate growth ability (weight, daily weight gains) and selected carcass characteristics during fattening period of Wagyu $\times$ Aberdeen Angus crossbred steers (F1). A total of 72 animals were evaluated over a period of 4 years. The observed animals were monitored from rearing (8 months) to slaughter (30 months). Statistical evaluation was performed by SAS 9.3 (GLM procedure); variables were corrected for effects of the year, season of birth and sire effect. Sire effect proved to be the most significant in our evaluation. Offsprings sired by Bull 1 had significantly $(\mathrm{P}<0.05)$ better growth ability than offsprings of other two tested bulls. Slaughter analysis of tested steers showed, that mean value of dressing percentage was $55.61 \%$. Significantly highest dressing percentage was found for Bull 1 offsprings $(56.72 \%, \mathrm{P}<0.05)$. The average carcass weight of tested steers was $443.46 \mathrm{~kg}$ and the highest carcass weight was again achieved by offsprings of Bull 1 (486.39 $\mathrm{kg} ; \mathrm{P}<0.05)$. Average value of beef marbling score was 5.21. Slaughter analyses of carcass cuts (cut-out, round, chuck, rump, tenderloin, shank, flank) and tallow showed that average weight of these lean cuts was $127.32 \mathrm{~kg}$ and tallow content was $39.31 \mathrm{~kg}$ at average. The highest values of these parameters were observed in offspring of bulls Bull $1(\mathrm{P}<0.05)$.
\end{abstract}

Keywords: growth, crossbreed, carcass cuts, marbling, sire

\section{INTRODUCTION}

Nowadays, beef cattle breeders are slowly starting to focus outside of traditional parameters, like bovine reproduction and growth ability. Breeders attention is now more than ever focused on improving beef quality parameters. One way to improve the quality and palatability of beef is to perform a targeted crossbreeding to achieve higher intramuscular fat content. One of the breeds that can improve intramuscular fat content is the Wagyu breed. This is the original Japanese breed traditionally bred for work and beef production (Evans, 1997; Pezza, 2014). The Wagyu cattle has medium body frame size and good growth ability (Porter and Stone, 2008). Daily gains can be around $900 \mathrm{~g}$, dressing percentage should be around $64 \%$, and high values of beef marbling score (BMS) are characteristic for Wagyu cattle (Cottle and Kahn, 2014). The 12-point scale of intramuscular fat in the Longissimus dorsi muscle is used in Japan for BMS visual evaluation (Cheng et al., 2015). Not only the content of intramuscular fat is higher, but also muscles have higher concentration of oleic acid 
and other monounsaturated fatty acids. Higher fat content is due to longer fattening period, which takes 30 to 35 months. Wagyu beef should contain at least 4-7 grams of fat per 100 grams of meat, while extremely marbled beef can have up to 40 grams per 100 grams of meat (Dikeman and Devine, 2014). Beef from Wagyu, also labeled as Kobe beef, is very high quality, but exports from Japan had been prohibited until recently. Therefore, other countries started to produce so-called Kobe style beef. Crossbreds of Wagyu and Aberdeen Angus are used for the production of this beef. Animals have to be at least $50 \%$ Wagyu and the fattening period have to be longer than 350 days. The "Kobe Style" beef is similar to Japanese Kobe, and it is praised for the same characteristics and high quality (Wagyu Breeding Program, 2016).

Knight et al. (1999) reported, that castration and conditions of fatenning have great influence on meat quality and growth ability. These results were also confirmed by Cottle and Kahn (2014). The aim of this paper is to evaluate selected fattening parameters and beef quality parameters of tested "Kobe style" fattened steers in in the conditions of Czech Republic.

\section{MATERIALS AND METHODS}

\section{Breeding management}

In total, growth ability and selected carcass characteristics of 72 Wagyu $\times$ Aberdeen Angus crossbreds steers (Fl) were evaluated over four-year period on two organic farms. The calves were castrated using rubber rings within 1 month after calving. Tested steers were reared at 8 months of age (average 226.25 days) and transported to beef farm for fattening. Fattening period was divided into two parts based on amount of energy contained in nutrition. Pre-fattening period lasted from 8 to 25 months of age. Feed composition consisted of silage with high dry matter content (16 kg), crushed barley $(3.5 \mathrm{~kg})$, soybean $(0.4 \mathrm{~kg})$ and synthetic vitamins. Second fattening period lasted 5 months (from 25 to 30 month of steers' age) and feed was composed of silage with high dry matter content (5.8 kg), corn (4 kg), molasses (2 kg) and synthetic vitamins. Feeding frequency was once a day on both farms. Feed intake was monitored individually for each steer and weighing was performed each month. Tested steers were during fattening period housed in free-stall stables with straw bedding and drinking water was supplied via ball drinkers. All the steers had access on grazing pasture (ad libitum) during whole year according climatic condition. The last three months of fattening period (27-30 months old) steers were housed in a stable. The steers were slaughtered at the age of 30 months (average age at slaughter was 908.41 days with differences from 901 to 925 days). Beef carcass quarters were aged (maturing) for 12 days; then they were cut into individual body parts and analysed.

\section{Statistical analyses}

Following growth ability parameters of crossbred steers were evaluated: live weight at rearing (g); daily weight gain (DWG) from birth to rearing reared (g); live weight at 12 months (kg); DWG at period from rearing to 12 months (g); live weight at 18 months (kg); DWG at period from 12 months to 18 months (g); live weight at 24 months (kg); DWG at period from 18 months to 24 months (g); live weight at 30 months (kg); DWG at period from 24 months to 30 months $(\mathrm{g})$.

Following slaughter analysis parameters were evaluated: dressing percentage (\%); carcass weight $(\mathrm{kg})$; cold carcass weight $(\mathrm{kg})$; beef marbling score (BMS); weight of chosen cuts ( $\mathrm{kg}$ - cut-out, round, chuck, rump, tenderloin, shank, flank); tallow content $(\mathrm{kg})$; and waste $(\mathrm{kg})$. In our study, we used 12-point scale, as is in accordance with Japan Beef Grading Association (Cheng et al., 2015).

Statistical evaluation was performed using SAS 9.3 (SAS/STAT ${ }^{\circledast} 9.3,2011$ ), GLM procedure. The model equation included the fixed effects: the year of birth (2011, n = 9; 2012, $\mathrm{n}=26$; 2013, $\mathrm{n}=29 ; 2014, \mathrm{n}=8$ ), the season of birth (March to May, $\mathrm{n}=8$; June to August, $\mathrm{n}=20$; September to November, $\mathrm{n}=26$; December to February, $\mathrm{n}=18$ ) and sire (Bull 1, $\mathrm{n}=14$; Bull 2, n = 14; Bull 3, n = 44). Tukey-Kremer test with significance level $(\mathrm{P}<0.05$ and $\mathrm{P}<0.01)$ was used for detail comparison of differences between levels of fixed effects.

\section{RESULTS}

\section{Basic statistics and model description}

Basic statistics for growth intensity and carcass characteristics are showed in Tab. I. The model equation for weight development was statistically significant for most of the months of growth $(\mathrm{P}<0.05)$ and explained from $20.6 \%$ (weight at slaughter) to $30.4 \%$ (weight at rearing) variability for growth ability parameters in the monitored months of growth. The year of birth effect and the season of birth effect was not significant. The effect of the sire was statistically significant for majority of the observed weights $(\mathrm{P}<0.05)$. Model equation for daily weight gains (DWG) have been significant and explained from 5.3\% (DWG from 8 to 28 months of age) to $30.4 \%$ (DWG until 8 months) variability. Within the model equation, the sire effect was again mostly significant for evaluated parameters $(\mathrm{P}<0.05)$. The remaining evaluated effects were statistically insignificant.

The model equation for post-slaughter evaluated parameters was statistically significant for most of the selected parameters of the slaughter analysis $(\mathrm{P}<0.05)$. This model equation explained from $16.9 \%$ (shank cut) to $22.3 \%$ (flank cut) variability for the evaluated parameters. As with the growth ability parameters, the sire effect was significantly $(\mathrm{P}<0.01)$ the most influential in most cases. The 
effect of the year and the season of birth wasn't significant for none of the monitored slaughter analysis parameters.

In further evaluation, the emphasis was placed on the differences between tested steers based on sire effect.

\section{Growth ability evaluation}

The results for the weight development of tested steers based on effect of the sire are shown in Fig. 1. The results for the DWG development of tested steers based on effect of the sire are shown in Fig. 2. Most importantly, Fig. 1 shows clear tendencies of better growth ability for Bull 1 offsprings compared to Bull 2 and Bull 3 offsprings ( $P<0.01$ ). Although, Fig. 2 shows high variability, there are numerous significantly higher $(\mathrm{P}<0.01)$ values for Bull 1 offsprings.

\section{Carcass characteristics evaluation}

Tables II to IV shows results of slaughter analysis and results for individual carcass cuts. Specifically, Tab. II shows the results for dressing percentage, carcass weight, cold carcass weight and BMS. The highest values of carcass and cold carcass weight was observed for Bull 1 offsprings, with average of
$486.39 \mathrm{~kg}(\mathrm{P}<0.05)$. Also, the dressing percentage was highest for Bull 1 offsprings, but the difference was not statistically significant compared to other sires. The highest BMS value was calculated for Bull 3 offsprings. Tab. III and IV contain weight comparison of the carcass cuts among tested steers based on their sires. The highest average weight of individual cuts were achieved by Bull 1 offsprings. However, statistically significant difference was only calculated for certain cuts (such as tenderloin, flank and cut-out; $\mathrm{P}<0.05)$, when compared to the offspring of the other bulls.

\section{DISCUSSION}

\section{Basic statistics and growth ability evaluation}

The average weight of tested steers was $238.56 \mathrm{~kg}$ at rearing (8 months old) in this study, which is about 1/5 lower than Jakubec and Ríha (2002) recommended at this age. Also, according to the beef performance control (CSCHMS, 2015) the average weight of Aberdeen Angus crossbreds should be around $270 \mathrm{~kg}$. This difference can be explained by low heritability and environmental factors (Szabó et al., 2006). The average daily

I: Basic characteristics for growth ability of crossbred steers

\begin{tabular}{|c|c|c|c|c|c|c|c|}
\hline Variable & $\mathbf{N}$ & $\mathbf{A M}$ & Sd & Min. & Max. & s.e. & CV \\
\hline average age at rearing (days) & 72 & 226,25 & 8.46 & 219 & 234 & 1.11 & 3.74 \\
\hline live weight at rearing (kg) & 72 & 238.56 & 17.55 & 209 & 285 & 2.07 & 7.36 \\
\hline DWG until reared (g) & 72 & 857.27 & 72.13 & 735.78 & 1048.17 & 8.50 & 8.41 \\
\hline live weight at 12 months (kg) & 72 & 335.71 & 29.10 & 279 & 392 & 3.43 & 8.67 \\
\hline DWG at period from rearing to 12 months (g) & 72 & 798.69 & 136.90 & 501.48 & 1035.85 & 16.13 & 17.14 \\
\hline live weight at 18 months (kg) & 72 & 480.06 & 48.91 & 385 & 566 & 5.76 & 10.19 \\
\hline DWG at period from 12 months to 18 months (g) & 72 & 791.12 & 134.94 & 515.18 & 1030.37 & 15.90 & 17.06 \\
\hline live weight at 24 months (kg) & 72 & 624.01 & 67.76 & 494 & 719 & 7.99 & 10.86 \\
\hline DWG at period from 18 months to 24 months (g) & 72 & 788.99 & 125.01 & 520.66 & 1035.85 & 14.74 & 15.83 \\
\hline live weight at 30 months (kg) & 72 & 796.74 & 79.11 & 629 & 911 & 9.32 & 9.93 \\
\hline DWG at period from 24 months to 30 months ( $\mathrm{g}$ ) & 72 & 946.63 & 82.66 & 723.45 & 1096.13 & 9.74 & 8.81 \\
\hline Dressing percentage (\%) & 72 & 55.61 & 1.17 & 54.17 & 58.99 & 0.14 & 2.11 \\
\hline Carcass weight (kg) & 72 & 443.46 & 48.63 & 341 & 535 & 5.73 & 10.97 \\
\hline Cold carcass weight (kg) & 72 & 434.59 & 47.66 & 334.18 & 524.3 & 5.62 & 10.97 \\
\hline BMS & 72 & 5.21 & 0.63 & 4 & 7 & 0.07 & 12.03 \\
\hline Cut-out (kg) & 72 & 192.42 & 21.16 & 147.81 & 231.9 & 2.49 & 11.00 \\
\hline Round (kg) & 72 & 48.34 & 5.31 & 37.26 & 58.46 & 0.63 & 10.98 \\
\hline Chuck (kg) & 72 & 39.87 & 4.38 & 30.74 & 48.24 & 0.52 & 10.99 \\
\hline Rump (kg) & 72 & 21.29 & 2.36 & 16.44 & 25.8 & 0.28 & 11.08 \\
\hline Tenderloin (kg) & 72 & 4.43 & 0.49 & 3.41 & 5.35 & 0.06 & 10.97 \\
\hline Shank (kg) & 72 & 10.02 & 1.13 & 7.75 & 12.16 & 0.13 & 11.23 \\
\hline Flank (kg) & 72 & 3.37 & 0.39 & 2.57 & 4.05 & 0.05 & 11.64 \\
\hline Tallow (kg) & 72 & 39.31 & 4.30 & 30.24 & 47.45 & 0.51 & 10.95 \\
\hline Waste (kg) & 72 & 75.54 & 8.37 & 57.96 & 90.9 & 0.99 & 11.08 \\
\hline
\end{tabular}

DWG - daily weight gain; $\mathrm{N}$ - number of observing; AM - aritmetic means; Sd - standard deviation; min. - minimal value; max. - maximal value; s.e. - standard error of aritmetic means; CV - coefficient of variance (\%). 


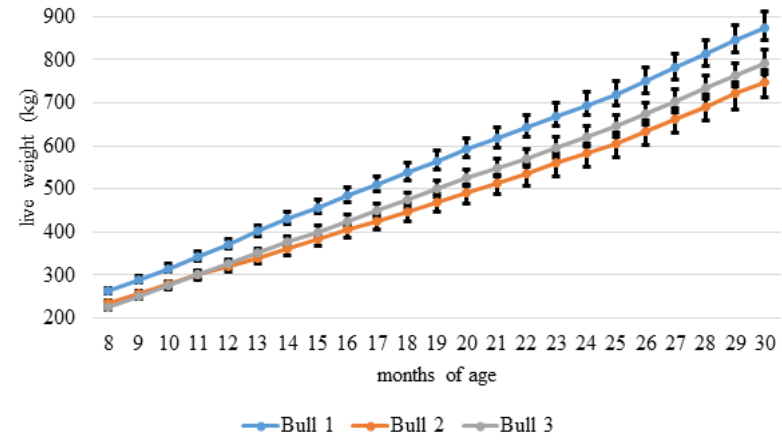

1: Weight development of tested steers based on their sires

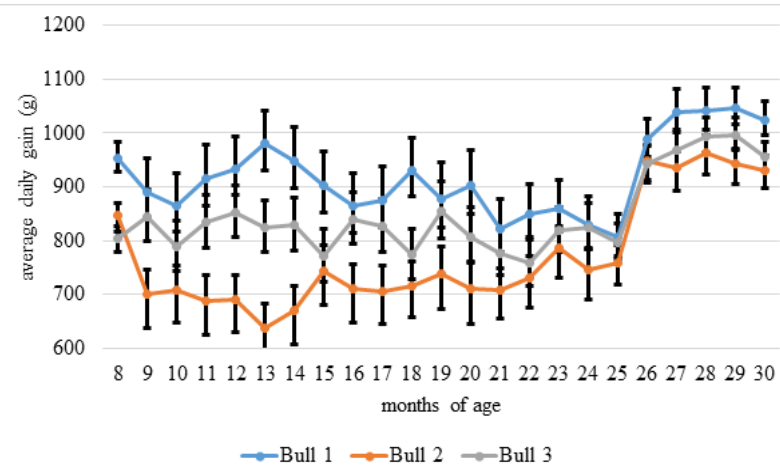

2: Daily weight gain development of tested steers based on their sires

II: Slaughter analysis evaluation of fattened steers based on their sires

\begin{tabular}{cccccc}
\hline \multirow{2}{*}{ Effect } & \multirow{2}{*}{ Group } & Dressing percentage & Carcass weight & Cold carcass weight & BMS \\
\cline { 3 - 6 } & & LSM \pm SEM & LSM \pm SEM & LSM \pm SEM & LSM \pm SEM \\
\hline \multirow{2}{*}{ Sire } & Bull 1 & $56.72 \pm 0.54$ & $496.32 \pm 22.32^{\mathrm{a}}$ & $486.39 \pm 21.88^{\mathrm{a}}$ & $5.24 \pm 0.21$ \\
& Bull 2 & $55.26 \pm 0.44$ & $414.35 \pm 18.07^{\mathrm{b}}$ & $406.07 \pm 17.71^{\mathrm{b}}$ & $5.11 \pm 0.17$ \\
& Bull 3 & $55.57 \pm 0.41$ & $440.83 \pm 16.72$ & $432.01 \pm 16.38$ & $5.60 \pm 0.16$ \\
\hline
\end{tabular}

LSM - least square means; SEM - standard error of last square means.

Different letters in columns means statistical significance $a-b \ldots P<0,05$.

III: Evaluation of results for slaughter bull sires slaughter analysis - continued

\begin{tabular}{cccccc}
\hline Effect & Group & $\begin{array}{c}\text { Cut-out } \\
\text { LSM } \pm \text { SEM }\end{array}$ & $\begin{array}{c}\text { Round } \\
\text { LSM } \pm \text { SEM }\end{array}$ & $\begin{array}{c}\text { Chuck } \\
\text { LSM } \pm \text { SEM }\end{array}$ & $\begin{array}{c}\text { Rump } \\
\text { LSM } \pm \text { SEM }\end{array}$ \\
\hline Sire & Bull 1 & $215.88 \pm 9.69^{\mathrm{a}}$ & $53.81 \pm 2.45$ & $44.32 \pm 2.03$ & $23.58 \pm 1.10$ \\
& Bull 2 & $179.69 \pm 7.84^{\mathrm{b}}$ & $45.22 \pm 1.99$ & $37.31 \pm 1.64$ & $19.93 \pm 0.89$ \\
& Bull 3 & $191.12 \pm 7.25$ & $48.15 \pm 1.84$ & $39.72 \pm 1.52$ & $21.23 \pm 0.82$ \\
\hline
\end{tabular}

LSM - least square means; SEM - standard error of last square means.

Different letters in columns means statistical significance $a-b \ldots P<0,05$.

IV: Evaluation of results for slaughter bull sires slaughter analysis - continued

\begin{tabular}{ccccccc}
\hline \multirow{2}{*}{ Effect } & \multirow{2}{*}{ Group } & Tenderloin & Shank & Flank & Tallow & Waste \\
\cline { 3 - 7 } & & LSM \pm SEM & LSM \pm SEM & LSM \pm SEM & LSM \pm SEM & LSM \pm SEM \\
\hline \multirow{2}{*}{ Sire } & Bull 1 & $4.95 \pm 0.22^{\mathrm{a}}$ & $11.06 \pm 0.53$ & $3.84 \pm 0.18^{\mathrm{a}}$ & $43.92 \pm 1.98^{\mathrm{a}}$ & $85.04 \pm 3.82^{\mathrm{a}}$ \\
& Bull 2 & $4.15 \pm 0.18^{\mathrm{b}}$ & $9.39 \pm 0.43$ & $3.14 \pm 0.14^{\mathrm{b}}$ & $36.75 \pm 1.60^{\mathrm{b}}$ & $70.48 \pm 3.09^{\mathrm{b}}$ \\
& Bull 3 & $4.41 \pm 0.17$ & $10.01 \pm 0.40$ & $3.33 \pm 0.13$ & $39.10 \pm 1.48$ & $74.93 \pm 2.86$ \\
\hline
\end{tabular}

LSM - least square means; SEM - standard error of last square means.

Different letters in columns means statistical significance a-b... $\mathrm{P}<0,05$. 
weight gain until rearing was $857.27 \mathrm{~g}$. According to Bjelka et al. (2007), DWG for calves grazing with their mothers should not fall below $1 \mathrm{~kg}$ until rearing. Animals bred in classical Japanese conditions for Wagyu fattening reached $290 \mathrm{~kg}$ at the age of 9 months, and $755 \mathrm{~kg}$ at the end of fattening - 29 months old (Motoyama et al., 2016). In comparison, an average weight of $262.94 \mathrm{~kg}$ (9 months old) and $767.44 \mathrm{~kg}$ (30 months old) was achieved in our study.

Also, Cottle and Kahn (2014) observed an average weight of $290 \mathrm{~kg}$ for 10 months old Wagyu cattle, which is a higher than in our tested group. On the other hand, at the age of 30 months they only achieved average weight of $725 \mathrm{~kg}$, which is lower compared to our steers. These differences may be due to different nutrition and also due to castration effect, because steers have worse growth ability and lower dressing percentage compared to bulls (Knight et al., 1999; Purchas et al., 2002). Additionally, Yamada and Nakanishi (2012) reached average weight of $287 \mathrm{~kg}$ for 10 months old and $796.74 \mathrm{~kg}$ for 30 months old purebred Wagyu cattle, which are both higher compared to our steers. Less intensive growth rate and a less favourable carcass composition compared to bulls is characteristic for steers. In our study, the average DWG was $791.77 \mathrm{~g}$ for steers in age period from 8 to 25 months and $979.03 \mathrm{~g}$ in the fattening period (from 25 to 30 months old). According to Albertí et al. (2008), the average DWG for medium body frame size breeds should be more than 1 000g in traditional fattening systems. In contrast, Motoyama et al. (2016) achieved average DWG of $770 \mathrm{~g}$ in traditional fattening of Wagyu steers in the period from rearing to the age of 29 months. Those gains are slightly lower compared to our monitoring, in which average gains were $838.67 \mathrm{~kg}$ per day for 10 to 30 months old steers. Yamada and Nakanishi (2012) reported only 670 g DWG in the same period. From chosen effects on the growth ability of steers in our study, the effect of the sire has proven to be the most influential for average DWG and weight in tested period. These findings may be attributed, outside of the external environment influences, to the individual genetic predisposition. Our evaluation has shown strong influence of steers' sires on fattening parameters. Similarly, significant influence of sire on growth abilities was also demonstrated in the study of Bartoň et al. (2001) and Gregory et al. (1991).

\section{Slaughter analysis}

Wagyu beef has a high biological value and balanced marbling. Traditional fattening of Wagyu cattle lasts 30 months, when they should reach weight of $725 \mathrm{~kg}$. Carcass comprises of muscles $-47.7 \%$, fat $-41.72 \%$ and bones $-10.6 \%$ (Gotoh et al., 2014). In recent years, the percentage of the intramuscular fat content is increasing, exceeding over 30\% (Horii et al., 2009; Albrecht et al.,
2011). In our study, the average dressing percentage of crossbred steers at the age of 30 months was $55.61 \%$. However, purebreds should achieve higher dressing percentage in both cases. In the case of Aberdeen Angus it should be around 61\%, according to the Aberdeen Angus breeding program (2016) and in Wagyu case it ranges from 60 to $70 \%$ (Gotoh et al., 2014). Nevertheless, for example Bartoň et al. (2006) described average dressing percentage for Aberdeen Angus bulls $58 \%$. The differences in dressing percentage can be explained by different fattening conditions (for example intensive fattening $\mathrm{x}$ semi intensive fattening) like confirmed Nogalski et al. (2014). Additionally, Cottle and Kahn (2014) have reported an average dressing percentage of $64.82 \%$ for 30 months old fattened steers. All mentioned studies reported much higher dressing percentage compared to ours, which may be due to different fattening conditions. Slaughter analysis of fattened steers also revealed significant differences in the proportion of individual cuts based on their genetic background, i.e. sire effect. The average carcass weight of tested steers at the age of 30 months was $443.46 \mathrm{~kg}$. In contrast, Wagyu bulls reached $470 \mathrm{~kg}$ at the age of 30 months (Cottle and Kahn, 2014). The effect of the sire was also demonstrated for carcass weight. Average value for BMS was 5.21 at the age of 30 months in this study. The average BMS for Wagyu breed should reach values between 6-7 (Cottle and Kahn, 2014). In the past 14 years, Cottle and Kahn (2014) had been evaluating BMS of Wagyu cattle (Japanese black) at age from 24 to 30 months reporting average value of 5.76, which is slightly higher to our results. Similarly, McAllister et al. (2011) observed mostly higher BMS values (5.42) for Aberdeen Angus cattle in USA fattening conditions. Contrary, Aberdeen Angus cattle in condition of central Europe seems to achieve lower BMS, as in the study of Albrecht et al. (2006), in which German Angus cattle scored even lower than Galloway breed when compared at age of 24 months. This reflects slightly different breeding goals for Aberdeen Angus. Higher values for those studies can be explained by the individuality of animals, their genetics and by differences in nutrition strategy. Furthermore, the average weight of individual cuts of carcass was evaluated. Lean cuts (round, chuck, rump, tenderloin, shank, flank) averaged at $127.32 \mathrm{~kg}$ and the tallow content was $39.31 \mathrm{~kg}$ at average. Contrary, Yaamady and Nakanishi (2012) reported average lean cuts weight of $115 \mathrm{~kg}$ and tallow weight of $63.7 \mathrm{~kg}$ for their fattened steers. Slaughter analysis of tested steers in our study clearly demonstrated significant influence of the genetic background, i.e. the effect of the sire in our study, on the weight of individual carcass cuts. 


\section{CONCLUSION}

In conclusion, cattle fattening, resp. steers fattening is influenced by not only by environmental effects but also by genetic predisposition. Influence of factors, like the year and the season of birth, can be minimized by providing good breeding conditions and balanced feed ration. Genetic predisposition, respectively sire effect had manifested primarily in the same breeding condition in our study. Therefore, it is necessary to select potential genetic improver for growth parameters and beef quality characteristics in selection scheme. On the other hand, we can conclude, that crossbreeds Wagyu x Aberdeen Angus steers fattening in condition of Czech Republic cannot be effective. The main advantage of Wagyu breed is marbling, which is associated with enhanced palatability properties. Better realization, respective effectivity of fattening can be achieved only if marbling will be taken into the account by cutting in Czech slaughterhouses.

\section{Acknowledgment}

The study was supported from the „S” grant of MŠMT ČR.

\section{REFERENCES}

ALBERTÍ, P., PANEA, B., SANUDO, C., OLLETA, J. L., RIPOLL, G., ERTBJERG, P., CHRISTENSEN, M., GIGLI, S., FAILLA, S., CONCETTI, S., HOCQUETTE, J. F., JAILLER, R., RUDEL., S., RENAND, G., NUTE, G. R., RICHARDSON, R. I. and WILLIAMS, J. L. 2008. Live weight, body size and carcass characteristics of young bulls of fifteen European breeds. Livest. Sci., 114(1): 19-30.

ALBRECHT, E., GOTOH, T., EBARA, F., XU, J. X., VIERQUTZ, T., NÜRNBERQ, G., MAAK, S. and WEGNER, J. 2011.Cellular conditions for intramuscular fat deposition in Japanese Black and Holstein steers. Meat Sci., 89(1): 13-20.

ALBRECHT, E., TEUSCHER, F., ENDER, K. and WEGNER, J. 2006. Growth and breed related changes of marbling characteristics in cattle. J. Anim. Sci., 84(5): 1067-1075.

BARTOŇ, L., ŘEHÁK, D., TESLÍK, V., BUREŠ, D. and ZAHRÁDKOVÁ R. 2006. Effect of breed on growth performance and carcass composition of Aberdeen Angus, Charolais, Hereford and Simmental bulls. Czech J. Anim. Sci., 51(2): 47-53.

BARTOŇ, L., TESLÍK, V., HERRMANN, H., ZAHRÁDKOVÁ, R. and BUREŠ, D. 2001. Effects of fattening system on meat performance of crossbred bulls and steers sired by Gascon and Charolais bulls. Czech J. Anim. Sci., 46(4): 172-178.

BJELKA, M., DUFEK, A., ŠUBRT, J. and HOMOLA, M. 2007. Možnosti extenzivní produkce masa v ČR [in Czech: Possibilities of extensive meat production in the Czech Republic]. In: Sborník príspèvkü z mezinárodního semináre: Výkrm skotu a nové metody hodnoceníkonzervovaných krmiv. VÚCHS Rapotín, pp. 4-12.

COTTLE, D. and KAHN, L. 2014. Beef cattle: production and trade. Melbourne: CSIRO Publishing.

CSCHMS. 2015. Uzávèrka KUMP aberdeen angus [Online]. Praha: Český svaz chovatelů masného skotu. Available at: http://www.cschms.cz/DOC-SLECHTENI-kump/298-Uzaverky-KUMP-AA.pdf [Accessed: 2017, March 18].

CSCHMS. 2016. Aberdeen Angus breeding program. 2016. [Online]. Praha: Český svaz chovatelů masného skotu. Available at: http://www.cschms.cz/DOC_SLECHTENI_program/126_Slechtitelsky_program_AA.pdf [Accessed: 2017, March 18].

CSCHMS. 2016. Wagyu Breeding Program. [Online].Praha: Český svaz chovatelů masného skotu. [cit.201703-18]. Available at: http://www.cschms.cz/DOC_SLECHTENI_program/144_Slechtitelsky_program_ WA.pdf [Accessed: 2017, March 18].

DIKEMAN, M. and DEVINE, C. 2014. Encyclopedia of Meat Sciences. $1^{\text {st }}$ Edition. Amsterdam: Elsevier Academic Press. EVANS, T. M. 1997. A dictionary of Japanese loanwords. Westport: Greenwood Press.

GARRICK, D. J. and RUVINSKY, A. 2015. The genetics of cattle. $2^{\text {nd }}$ Edition. Wallingford: CABI.

GOTOH, T., TAKAHASHI, H., NISHIMURA, T., KUCHIDA, K. and MANNEN, H. 2014. Meat produced by Japanese Black cattle and Wagyu. Animal Frontiers, 4(4): 46-54.

GREGORY, K. E., CUNDIFF, L. V. and KOCH, R. M. 1991. Breed effects and heterosis in advanced generation of composite populations for growth traits in both sexes of beef cattle. J. Anim. Sci., 69(8), 3202-3212.

HORII, H. Y., SAKURAI, Y., KANBE, K., KASAI, K., ONO, T., ASADA, T., MORI, M., KOBAYASHI, A., IGUCHI, M., YAMADA, M., HAYASHI, A., and HODATE, K., 2009. Relationship between Japanese Beef Marbling Standard numbers and intramuscular lipid in M. longissimus thoracis of Japanese Black steers from 1996 to 2004. Anim. Sci. J., 80(1): 55-61.

CHENG, W., CHENG J. H., SUN, D. W. and PU, H. 2015. Marbling analysis for evaluating meat quality: Methods and Techniques. Compr Rev Food Sci Food Saf., 14(5): 523-535.

JAKUBEC, V. and ŘÍHA,J. 2002. Návrh systémů hybridizace u skotu a ovcí. [in Czech:Design of hybridization systems in cattle and sheep]. In: Využití diferenciaci mezi masnými plemeny k efektivní produkci. VÚCHS Rapotín, pp. 5-49. 
KNIGHT, T. W., COSGROVE, G. P., LAMBERT, M. G. and DEATH, A. F. 1999. Effect of method and age at castration on growth rate and meat quality of bulls. New. Zeal. J. Agr. Res., 42(3): 255-268.

MCALLISTER, C. M., SPEIDEL, S. E., CREWS JR., D. H. and ENNS, R. M. 201l. Genetic parameters for intramuscular fat percentage, marbling score, scrotal circumference, and heifer pregnancy in Red Angus cattle. J. Anim. Sci., 89(7): 2068-2072.

MOTOYAMA, M., SASAKI, K. and WATANABE, A. 2016. Wagyu and the factors contributing to its beef quality: A Japanese industry overview. Meat Science, 120: 10-18.

NOGALSKI,Z., WIELGOSZ-GROTH, Z., PURWIN, C., NOGALSKA, A., SOBCZUK-SZUL, M., WINARSKI, R. and POGORZELSKA, P. 2014. The effect of slaughter weight and fattening intensity on changes in carcass fatness in young Holstein-Friesian bulls. Ital. J. Anim. Sci., 13: 66-72.

PEZZA, K. 2014. Backyard Farming: Raising Cattle for Dairy and Beef. New York: Hatherleight Press.

PORTER, V. and STONE, L. M. 2008. The Field Guide to Cattle. Minneapolis: Voyageur press.

PURCHAS, R. W., BURNHAM, D. L. and MORRIS, S. T. 2002. Effect of growth potential and growth path on tenderness of beef longissimus muscle from bulls and steers. J. Anim. Sci., 80(12): 3211-3221.

SZABÓ, F., NAGY. L., DÁKAY, I., MÁRTON. D., TÖRÖK, M. and BEENES, Z. 2006. Effect of breed, age of dam, birth year, birth season and sex on weaning weight of beef calves. Livestic. Sci., 103(1-2): 181-185.

YAMADA, T. and NAKANISHI, N. 2012. Effects of the roughage/concentrate ratio on the expression of angiogenic growth factors in adipose tissue of fattening Wagyu steers. Meat Sci., 90(3): 807-813.

Renáta Toušová: tousova@af.czu.cz 